\title{
Firm Size and Financial Performance Among Listed Banks of Emerging Economies in Africa
}

\author{
Olaoluwa Elsie Umukoro ${ }^{1}$, Olubukola Ranti Uwuigbe ${ }^{1}$, Imoleayo Obigbemi ${ }^{1}$, Balogun Sheriff Babajide ${ }^{2}$, Damilola \\ Felix Eluyela ${ }^{3} \&$ Inua Ofe $^{4}$ \\ ${ }^{1}$ Department of Accounting, Covenant University, Ota, Nigeria \\ ${ }^{2}$ Department of Accountancy, The Federal Polytechnic, Ilaro, Nigeria \\ ${ }^{3}$ Department of Accounting and Finance, Landmark University, Omu Aran, Nigeria \\ ${ }^{4}$ Department of Financial Studies, National Open University, Nigeria \\ Correspondence: Damilola Felix Eluyela, Department of Accounting and Finance, Landmark University, Omu Aran, \\ Nigeria.
}

Received: April 28, 2020

Accepted: June 2, 2020

Online Published: February 6, 2021

doi:10.5430/rwe.v12n1p340

URL: https://doi.org/10.5430/rwe.v12n1p340

\begin{abstract}
The continuous increase in the size of various firms and listed banks, has necessitated the need to empirically examine the effect firm size has on the financial performance of listed banks in Africa. This is because some organisations and institutions have in time past failed to fulfill their going concern objective despite their large firm size balance. This study examined the effect firm size has on the three levels of cash flow of emerging economies in listed banks in Africa. The study employed the use of multiple regression analysis with the aid of the STATA statistical software tool. The result obtained revealed that for the operating level of cash flow, all countries used in this paper, with the exception of Kenya should continue to employ the independent variable as a corporate strategy method as it increases operating cash inflow. The financing level of cash flow results recommended that all countries except Nigeria should continue to utilize firm size as a significant value was obtained from the regression. The investing level of cash flow results produced a significant P-value for all countries with the exception of Botswana. The study, therefore, recommended that listed banks in Kenya, Nigeria and Botswana should apply caution in employing the firm-size corporate strategy method. This is because it doesn't guarantee cash inflow in all three levels of cash flows.
\end{abstract}

Keywords: firm size, operating cash flow, financing cash flow, investing cash flow

\section{Introduction}

Financial performance is a major indicator and reference point for every stakeholder in most organizations around the world (Umukoro et al., 2020; Ojeka et al., 2019; Nwanji et al., 2020; Okere et al., 2019). This is because the more income an organization is able to generate, the easier it is for management to reward her stakeholders, make profits and fulfill all financial obligations. It has therefore become very necessary for management to engage in ethical activities that'll bring about income generation and aid the longevity of a given firm (Umukoro, et al., 2020).

This study employs the use of the three levels of cash flow to measure the financial performance of listed banks of emerging economies in Africa. Cash flow is employed because it measures the amount of actual monies received during any given financial year. Over the years, studies such as (Ijeoma, 2014; Ezeagba 2014; Ozordi et al., 2019) have revealed that the net profit figure should not be relied solely upon as it is prone to various financial anomalies and creative accounting practices. Studies such as (Osagie 2016; Tutor 2018; Umukoro et al., 2020) have pointed out that the cash flow statement gives a clear picture of the financial state of health of any given organization.

Uwuigbe (2019) has revealed that firm size is one of the corporate strategies that organisations utilize to gain a competitive edge over their other contemporaries. One of the main reasons why the big 4 audit firms earned their global relevance is largely because of their size (Uwuigbe 2019). The size of a given firm has been said to influence their ability to make profits (Mulyono, \& Khairurizka, 2009; Jafari, Gord \& Beerhouse, 2014; Otekunrin et al., 2019). In recent times, listed banks such as Cresta Bank, Intercontinental Bank, Diamond bank, Skye Bank, VBS Bank etc have either collapsed or had to merge or be acquired despite having an enviable firm size. The above-listed banks 
recorded very large monetary value in the total assets section of their various statements of financial position and still folded up. Although banks such as Unity Bank, Guaranty Trust Bank Africa, United Bank of Africa have large total assets and are still in existence.

Hilgen (2015) and Osagie (2016) in their research concluded that the total assets of a given institution have nothing to do with the organisation's ability to generate more cash inflows or profits. Although the above literature was limited in sample size and (Osagie, 2016) only examined the operating level of cash flow in his study. This study goes a step further by examining all three levels of cash flow while employing the STATA statistical software to establish whether a vital relationship exists or not.

This study is embarked upon to determine If there is any effect between the firm size of any given listed bank of emerging economies in Africa and the three levels of cash flow during the financial year. In reality, various listed banks in Africa have over the years invested heavily in items that constitute their total assets, examples include their buildings. African banks are seen to have similar structures and edifice with foreign banks. This study wants to examine if these structures and other acquired assets have any significant effect on the organization aim of achieving her going concern objective.

It is against this line of thought that the following hypothesis emanated from:

$\mathrm{H}_{0}$ : There is no significant relationship between firm size and the operating level of cash flow in listed banks of Emerging Economies in Africa.

$\mathrm{H}_{0}$ : There is no significant relationship between firm size and the financing level of cash flow in listed banks of Emerging Economies in Africa.

$\mathrm{H}_{0}$ : There is no significant relationship between firm size and the investing level of cash flow in listed banks of Emerging Economies in Africa.

\section{Literature Review}

Osagie (2016) revealed that the age of the firm has an insignificant negative relationship with the operating cash flow. However, the size of a firm has a positive and insignificant relationship with operating cash flow. The study is limited in sample size and a methodological gap was observed during the review. This study goes a step further by expanding the sample size to include other listed banks in emerging economies in Africa and delving deeper by examining all three levels of cash flow.

Hilgen (2015) study was limited to the listed firms in Germany. Variables such as firm size, leverage, bank debts and liquid assets were employed in the analyses. The study only measures the impact of the above-listed variables on cash holding other aspects of cash flow were not analysed. This research work was limited to companies listed on the Tehran stock exchange market and it explored the effect liquidity, firm size and debt had on investment-cash flow sensitivity. Purposive sampling was employed in this study and it failed to capture other variables such as the operating and financing cash flow levels. Only the T-statistics result was analysed and the overall effect of the dependent variables on the independent variable was not examined, the study also made use of ordinary least regression instead of the use of panel data analysis. Hilgen (2015) stated that firm size has a negative impact on stock return, this study improves on the article by investigating what kind of relationship exists between firm size and financial performance of listed banks in Africa.

African Development Bank, (2019) stated that firms that have a large size are more productive, which aids more revenue and companies that have a large firm size pay their workers a higher remuneration than organisations with relatively smaller firm size. Flipse (2012) evaluated the determinants of cash holding in a case study of European countries. Variables tested include firm size, cash to asset ratio, cash flow risk and financial leverage. The operating, financing and investment activity figures of the cash flow statement were not considered in this study and the study's sample size consists of fifteen companies

Conclusively, Soumaya (2012) evaluated the effect of firm size, debt ratio and liquidity on investment-cash flow. Other levels of cash flow were not investigated in this study. The study was limited to French firms and only the investment cash flow figure was utilized in the study meanwhile Tayem, (2017) concluded that firm size and cash substitutes have a negative and significant effect on cash holdings. Dang et al. (2018) also examined the relevance of firm size in corporate finance and established the significance. They also stated that the significance of firm size is sometimes dependent on the sector and situations. 


\section{Methodology}

The researcher made use of the expo-facto research design subjecting the dependent and independent variables to a panel data regression analysis. Secondary data was used to empirically validate this work as data was collated from the financial statements of the selected listed banks. STATA software tool was utilized.

The population of this study consists of all listed banks in Emerging Economies in Africa 2019, (IMF, 2019: Africa business, 2019) (IMF 2019). South-Africa was added to the sample size of this study because it is the only African country ranked among the BRICS emerging economies in the world (BRICS, 2019).

The study narrowed its sample size to include emerging economies only because emerging markets/economies are economies that are moving away from the traditional methods of funding their economies and they are the economies that emulate their foreign counterparts by investing in their outlook, this is to attract more customers and investors. They adapt or adopt various strategies that aid increase in cash flow, visibility, financial stability and global relevance. African Development Bank (ADB) 2019 has stated that firm size is one of the strategies that enhance cash flow and visibility. IMF 2019 and BRICS 2019 have stated African countries that fall in this category and this study utilized data from countries whose financial statements were audited, published and available from the year 2013-2018.

The countries selected include Ghana, Nigeria, South-Africa, Botswana, Kenya and Tanzania. The countries were selected based on the availability of the financial statements for the time frame (2013-2018) of the study. Financial statements of some listed banks in Emerging Economies in Africa between the years 2013-2018 were not available for public consumption and research purposes, hence their exclusion from the sample size (Umukoro et al., 2020; Ademola et al., 2020a; 2020b; Ozordi et al., 2020). This study employs data from only listed banks in these regions majorly because the Stock Exchange Markets are regulated and data obtained from there have at least been validated by external auditors. A total of thirty-eight listed banks in Africa have been selected as the Sample size. The regression analysis applied the robust formula during the statistical analysis (Umukoro et al 2020; Chukwu et al., 2019; Eluyela et al., 2019a; 2019b; Oladipo et al., 2019).

\section{Research Models}

This model was adapted from the work of Umukoro et al (2020). The model is stated as follows:

$$
\begin{aligned}
& \text { OPCF }=\beta_{0}+\beta_{1} \mathrm{FS}_{\text {it }}+\beta_{2} \mathrm{BS}_{\text {it }}+\beta_{3} \mathrm{FL}_{\text {it }}+\beta_{4} \mathrm{BC}_{\text {it }}+\mathrm{U}_{\text {it }} \\
& \text { FINCF }=\beta_{0}+\beta_{1} \mathrm{FS}_{\text {it }}+\beta_{2} \mathrm{BS}_{\text {it }}+\beta_{3} \mathrm{FL}_{\mathrm{it}}+\beta_{4} \mathrm{BC}_{\text {it }}+\mathrm{U}_{\text {it }} \\
& \mathrm{INVCF}=\beta_{0}+\beta_{1} \mathrm{FS}_{\text {it }}+\beta_{2} \mathrm{BS}_{\text {it }}+\beta_{3} \mathrm{FL}_{\text {it }}+\beta_{4} \mathrm{BC}_{\text {it }}+\mathrm{U}_{\text {it }}
\end{aligned}
$$

Where:

$\beta_{0}$ is the intercept

$\beta_{1-4}$ is the coefficients of the explanatory(control) variables

$\mathrm{U}_{\mathrm{it}}$ is the error or disturbing term that absorbs the influence of omitted variables in proxies used.

\section{Results}

Table 1. Regression table for hypothesis (A) (Ghana)

\begin{tabular}{lllll}
\hline Operating cash flow & Coefficient & Standard error & t & Probability \\
\hline Firm Size & .2463266 & .995465 & 2.47 & 0.006 \\
\hline Board Size & 2.488049 & 6.150639 & 0.40 & 0.705 \\
\hline Leverage & 1.507393 & 1.97441 & 0.76 & 0.488 \\
\hline
\end{tabular}

Source: Author's Computation, (2019); Prob >F = 0.1466 (Fixed Result).

Decision: Accept Alternate: There is a significant relationship between firm size and the operating level of cash flow of listed banks in Ghana. 
Table 2. Regression table for hypothesis three (B) (Ghana)

\begin{tabular}{lllll}
\hline Financing cash flow & Coefficient & Standard error & T & Probability \\
\hline Firm Size & .0832991 & .0033014 & 5.33 & 0.000 \\
\hline Board Size & 1.220105 & 1.396233 & 0.87 & 0.382 \\
\hline Leverage & .0172818 & .2072317 & 0.08 & 0.933 \\
\hline
\end{tabular}

Source: Author's Computation, (2019); Prob >F = 0.000 (Random Result).

Decision: Accept Alternate: There is a significant relationship between firm size and the financing level of cash flow of listed banks in Ghana.

Table 3. Regression table for hypothesis three (C) (Ghana)

\begin{tabular}{lllll}
\hline Investing cash flow & Coefficient & Standard error & t & Probability \\
\hline Firm size & .9971517 & .15736 & 6.33 & 0.000 \\
\hline Board Size & -3.782516 & 20.53227 & -0.18 & 0.854 \\
\hline Leverage & -1.539325 & 11.67738 & -0.13 & 0.895 \\
\hline
\end{tabular}

Source: Authors Computation (2019); Prob >F = 0.000 (Random Result).

Decision: Accept Alternate: There is a significant relationship between firm size and the investing level of cash flow of listed banks in Ghana.

Table 4. Regression table for hypothesis three (A) (Nigeria)

\begin{tabular}{lllll}
\hline Operating cash flow & Coefficient & Standard Error & $\mathbf{t}$ & Probability \\
\hline Firm Size & .0477303 & .0090497 & 5.27 & 0.000 \\
\hline Board Size & 1.342508 & 1.224963 & 1.10 & 0.273 \\
\hline Leverage & .1108398 & .4301172 & 0.26 & 0.797
\end{tabular}

Source: Author's Computation, (2019). Prob >F = 0.000 (Random Result).

Decision: Accept Alternate hypothesis: There is a significant relationship between firm size and the operating level of cash flow of listed banks in Nigeria.

Table 5. Regression table for hypothesis three (B) (Nigeria)

\begin{tabular}{lllll}
\hline Financing cash flow & Coefficient & Standard Error & $\mathbf{t}$ & Probability \\
\hline Firm Size & -.0048556 & .0060167 & -0.81 & 0.420 \\
\hline Board Size & -.4745599 & 316147 & -3.03 & 0.133 \\
\hline Leverage & .107335 & 3.917777 & 2.77 & 0.421 \\
\hline
\end{tabular}

Source: Author's Computation, (2019); Prob >F = 0.000 (Random Result).

Decision: Accept Null hypothesis: There is no significant relationship between firm size and the financing level of cash flow of listed banks in Nigeria. 
Table 6. Regression table for hypothesis three (C) (Nigeria)

\begin{tabular}{lllll}
\hline Investing cash flow & Coefficient & Standard Error & $\mathbf{t}$ & Probability \\
\hline Firm Size & -.2163844 & .0478238 & -4.52 & 0.0000 \\
\hline Board Size & -1.260018 & 6.809936 & -0.19 & 0.853 \\
\hline Leverage & -1.07327 & 3.030397 & -0.35 & 0.723 \\
\hline
\end{tabular}

Source: Author's Computation (2019). Prob $>\mathrm{F}=0.003$ (Random Result).

Decision: Accept Alternate hypothesis: There is a significant relationship between firm size and the investing level of cash flow of listed banks in Nigeria.

Table 7. Regression table for hypothesis three (A) (South-Africa)

\begin{tabular}{lllll}
\hline Operating cash flow & Coefficients & Standard errors & $\mathbf{t}$ & Probability \\
\hline Firm size & .01815875 & .0095505 & 8.54 & 0.000 \\
\hline Board Size & -.0660831 & .0438731 & -1.51 & 0.132 \\
\hline Leverage & .027356 & .0380578 & 0.72 & 0.472 \\
\hline
\end{tabular}

Source: Author's computation (2019); Prob >F = 0.000 (Random Result).

Decision: Accept alternate hypothesis: There is a relationship between firm size and operating level of cash flow of listed banks in South-Africa.

Table 8. Regression table for hypothesis three (B) (South-Africa)

\begin{tabular}{lllll}
\hline Financing cash flow & Coefficients & Standard errors & $\mathbf{t}$ & Probability \\
\hline Firm size & .1472155 & .0246771 & 5.97 & 0.000 \\
\hline Leverage & .0375737 & .1110329 & 0.34 & 0.739 \\
\hline Board size & -.0110894 & .0790668 & -0.14 & 0.890 \\
\hline
\end{tabular}

Source: Author's computation (2019); Prob >F = 0.000 (Random Result).

Decision: Accept alternate hypothesis: There is a relationship between firm size and financing level of cash flow of listed banks in South-Africa.

Table 9. Regression table for hypothesis three (C) (South-Africa)

\begin{tabular}{lllll}
\hline Investing cash flow & Coefficients & Standard errors & $\mathbf{t}$ & Probability \\
\hline Firm Size & -.2148012 & .0242854 & -8.84 & 0.000 \\
\hline Leverage & .1701293 & .1012941 & 1.68 & 0.093 \\
\hline Board Size & -.1329723 & .0873911 & -1.52 & 0.128 \\
\hline
\end{tabular}

Source: Author's Computation (2019); Prob >F = 0.000 (Random Result).

Decision: Accept alternate hypothesis: There is a relationship between firm size and investing level of cash flow of listed banks in South-Africa. 
Table 10. Regression table for hypothesis three (A) (Botswana)

\begin{tabular}{lllll}
\hline Operating cash flow & Coefficients & Standard errors & t & Probability \\
\hline Firm Size & .0992217 & .0294964 & 3.36 & 0.001 \\
\hline Board size & -63.55076 & 89.30277 & 0.65 & 0.518 \\
\hline Leverage & 23.7493 & 39.9428 & 0.71 & 0.477 \\
\hline
\end{tabular}

Source: Author's Computation (2019); Prob >F = 0.006 (Random Result).

Decision: Accept alternate hypothesis: There is no relationship between firm size and operating level of cash flow of listed banks in Botswana.

Table 11. Regression table for hypothesis three (B) (Botswana)

\begin{tabular}{lllll}
\hline Financing cash flow & Coefficients & Standard errors & $\mathbf{t}$ & Probability \\
\hline Firm size & .0123691 & .0039211 & 3.15 & 0.001 \\
\hline Board size & 7.26486 & 58.5809 & 60.12 & 0.518 \\
\hline Leverage & 1.453638 & 5.241756 & -1.40 & 0.552 \\
\hline
\end{tabular}

Source: Author's computation (2019); Prob >F = 0.0028 (Random Result).

Decision: Accept alternate hypothesis: There is a relationship between firm size and financing level of cash flow of listed banks in Botswana.

Table 12. Regression table for hypothesis three (C) (Botswana)

\begin{tabular}{lllll}
\hline Investing cash flow & Coefficients & Standard errors & t & Probability \\
\hline Firm size & -.2764504 & .1659258 & -1.67 & 0.096 \\
\hline Board size & 750.3534 & 602.42319 & 1.08 & 0.281 \\
\hline Leverage & -98.96285 & -124.2261 & 0.80 & 0.213 \\
\hline
\end{tabular}

Source: Author's computation (2019); Prob >F = 0.0000 (Random Result).

Decision: Accept alternate hypothesis: There is a relationship between firm size and investing level of cash flow of listed banks in Botswana.

Table 13. Regression table for hypothesis three (A) (Kenya)

\begin{tabular}{lllll}
\hline Operating cash flow & Coefficients & Standard errors & t & Probability \\
\hline Firm size & -.0617139 & 0.0477219 & -1.29 & 0.266 \\
\hline Board size & -2.191219 & 1.678068 & -1.31 & 0.262 \\
\hline Leverage & 3.045643 & 1.048061 & 2.91 & 0.044 \\
\hline
\end{tabular}

Source: Author's computation (2019); Prob >F = 0.000 (Random Result).

Decision: Accept null hypothesis: There is no relationship between firm size and operating level of cash flow of listed banks in Kenya. 
Table 14. Regression table for hypothesis three (B) (Kenya)

\begin{tabular}{lllll}
\hline Financing cash flow & Coefficients & Standard errors & t & Probability \\
\hline Firm size & -.0223218 & .0112215 & -1.99 & 0.047 \\
\hline Board size & .1729467 & .3688333 & 0.47 & 0.639 \\
\hline Leverage & .5064993 & .2466661 & 2.05 & 0.423 \\
\hline
\end{tabular}

Source: Author's computation (2019); Prob >F = 0.000 (Random Result).

Decision: Accept alternate hypothesis: There is no relationship between firm size and financing level of cash flow of listed banks in Kenya.

Table 15. Regression table for hypothesis three (B) (Kenya)

\begin{tabular}{lllll}
\hline Investing cash flow & Coefficients & Standard errors & $\mathbf{t}$ & Probability \\
\hline Firm size & -.0767302 & .0273882 & -2.80 & 0.005 \\
\hline Board size & -.7846509 & 1.299696 & -0.60 & 0.546 \\
\hline Leverage & -1.77127 & 5663751 & -3.13 & 0.002 \\
\hline
\end{tabular}

Source: Author's computation (2019); Prob >F = 0.000 (Random Result).

Decision: Accept alternate hypothesis: There is no relationship between firm size and investing level of cash flow of listed banks in Kenya.

Table 16. Regression table for hypothesis three (A) (Tanzania)

\begin{tabular}{lllll}
\hline Operating cash flow & Coefficients & Standard errors & t & Probability \\
\hline Firm size & .6314206 & .007821 & 8.73 & 0.000 \\
\hline Board Size & -1.118688 & .6049197 & -1.83 & 0.080 \\
\hline Leverage & -.464694 & .3675659 & -1.26 & 0.221 \\
\hline
\end{tabular}

Source: Author's computation (2019); Prob >F = 0.0000 (Fixed Result).

Decision: Accept alternate hypothesis: There is a relationship between firm size and operating level of cash flow of listed banks in Tanzania.

Table 17. Regression table for hypothesis three (B) (Tanzania)

\begin{tabular}{lllll}
\hline Financing cash flow & Coefficients & Standard errors & $\mathbf{T}$ & Probability \\
\hline Firm size & .0051061 & .0007214 & 7.08 & 0.000 \\
\hline Board size & -.1134279 & -.1134279 & -1.64 & 0.101 \\
& & & & \\
\hline Leverage & -.0341282 & .0315395 & -1.08 & 0.279 \\
\hline
\end{tabular}

Source: Author's computation (2019); Prob >f $=0.0000$ (random result).

Decision: Accept alternate hypothesis: There is a relationship between firm size and financing level of cash flow of listed banks in Tanzania. 
Table 18. Regression table for hypothesis three (C) (Tanzania)

\begin{tabular}{lllll}
\hline Investing cash flow & Coefficients & Standard errors & $\mathbf{t}$ & Probability \\
\hline Firm size & -.2320293 & .002522 & -2.00 & 0.000 \\
\hline Board Size & .4773159 & 21531125 & 2.22 & 0.027 \\
\hline Leverage & .3186002 & .1156229 & 2.76 & 0.006
\end{tabular}

Source: Author's computation (2019); Prob >F = 0.0000 (Random Result).

Decision: Accept alternate hypothesis: There is a relationship between firm size and investing level of cash flow of listed banks in Tanzania.

Table 19. Comparative analysis table (firm size).

\begin{tabular}{lllllll}
\hline & Ghana & Nigeria & South-African & Botswana & Kenya & Tanzania \\
\hline $\begin{array}{l}\text { Operating } \\
\text { cash flow }\end{array}$ & Reject null & Reject null & Reject null & Reject null & Accept null & Reject null \\
\hline $\begin{array}{l}\text { Financing } \\
\text { cash flow }\end{array}$ & Reject null & Accept null & Reject null & Reject null & Reject null & Reject null \\
\hline $\begin{array}{l}\text { Investing } \\
\text { cash flow }\end{array}$ & Reject null & Reject null & Reject null & Accept null & Reject null & Reject null \\
\hline
\end{tabular}

Source: Author's computation (2019)

\section{Comparative Analysis Discussion}

The firm size figure of a given organisation is of utmost importance to its stakeholders. Hence management are always in the business of expanding their total assets base to attract more investors and income. The results obtained when firm size was regressed with the operating cash flow revealed that all listed banks in all countries utilized in this study except Kenya validate this claim. This means that the size of a firm truly attracts more customers and this explains why most listed banks continue to expand their total assets base and build structures similar to banks in developed countries and this is in tandem with (Jafari, Gord and Beerhouse, 2015; Soumaya, 2012 \& Tayem 2017). Kenya's result is in sync with Osagie's 2016 findings.

The financing cash flow segment of this analysis proved that the size of the firm goes further to attract more funds, other than funds from the core activities of the business. All countries utilized in this study except for Nigeria yielded a significant relationship. This goes further to buttress the point of Uwuigbe, (2019) that states the size of the firm is one of the reasons why the big four audit firms are able to compete on the global scale.

The Nigerian results in this segment are in tandem with reality as a lot of formerly listed banks had very large assets base, yet they are unable to attract more funds and investments. The investments cash flow also obtained similar results as stated above. All countries utilized in this study obtained a significant relationship except for Botswana. This means firm size has a significant link with the amount generated from investing cash flow but this is not absolute as Botswana's result produced an insignificant probability value. Botswana's result is in line with Osagie (2016) and not in tandem with (Mulyono \& Khairurizka, 2009), as their research concluded that firm size has a significant effect on stock returns.

There's a popular parlance that says that 'an individual with money and assets, has more access to viable businesses. Results obtained from this empirical study backs up this saying and also in line with prior studies (Soumaya 2012; Jafari, Gord \& Beerhouse 2015; Boriçi \& Kruja, 2016; Tayem, 2017).

\section{Contribution to Knowledge}

This study contributed to the study on firm size and financial performance of listed banks in Emerging Economies in Africa.

1. This study provides current empirical evidence on literature relating to firm size and financial performance of listed banks in Emerging Economies in Africa. 
2. This study measures the effect firm size has on the three levels of cash flow. Prior studies were limited to only one level of cash flow, while other studies employed the use of profitability values.

3. The model developed for this study serves as one of the contributions to knowledge as the model has been further advanced from Osagie's (2016) model to include the three levels of cash flow relevant in today's business world.

4. Prior studies were limited to listed banks in Nigeria. This study increased the sample size by including listed banks in emerging economies in Africa.

5. The study also includes control variables such as board size and financial leverage.

\section{Conclusion}

The study concludes that countries such as Kenya, Nigeria and Botswana should apply caution in employing the firm-size strategy method. This is because it doesn't guarantee cash inflow at all three levels of cash flows. The study also recommended that Deposit money banks in Emerging economies in Africa should develop corporate strategies that would boost their operating, financing and investing cash flow figures and also engage empirical evidence before adopting or adapting certain corporate strategies because the fact that a particular corporate strategy yields an increased financial performance for a particular bank does not automatically imply that the same result would be obtained in the next deposit money institution.

The result obtained revealed that listed banks in Ghana, South-Africa and Tanzania should continue to employ firm size as a corporate strategy method because a vital relationship was discovered from the regressed statistical result. The study admonishes other listed banks of countries utilized in this study to apply caution when utilizing firm size as a corporate strategy method, this is mainly because it does not have a significant and vital effect on all three levels of cashflow. Listed banks in Nigeria should only utilize our independent variable if they intend to increase the operating and investing level of cash flow as a non-vital result was obtained when the financial cash flow was regressed. For Botswana, listed banks should only utilize this corporate strategy method when they intend to increase their operating and financing cash flow level. Conclusively, listed banks in Kenya should not employ the use of our independent variable when looking for avenues to boost the operating level of cash flow as no important significance was obtained during the statistical computation but if they intend to increase the other levels (financing and investing) of cashflow, then firm size is a corporate strategy or dynamic worth utilizing as a vital relationship was established.

The study is limited to the banking industry in emerging economies in Africa. Firm size was the only independent variable examined in this study. Further studies should delve into other corporate strategies relevant in today's business world and expand the sample size to include other countries and other sectors.

\section{References}

Adegboyegun, A. E., Alade, M. E., Ben-Caleb, E., Ademola, A. O., Eluyela, D. F., \& Oladipo, O. A. (2020). Integrated reporting and corporate performance in Nigeria: evidence from the banking industry. Cogent Business and Management, 7(1). https://doi.org/10.1080/23311975.2020.1736866

Ademola, A. O., Ben-Caleb, E., Adegboyegun, A. E., Eluyela, D. F., Falaye, A. J., \& Ajayi, A. S. (2020b). Rotating and savings credit association (ROSCAs): A veritable tool for enhancing the performance of micro and small enterprises in Nigeria. International Asian Economic and Financial Review, 10(2), 189-199. https://doi.org/10.18488/journal.aefr.2020.102.189.199

Ademola, A. O., Ben-Caleb, E., Madugba, J. U., Adegboyegun, A. E., \& Eluyela, D. F. (2020a). International public sector accounting standards (IPSAS) adoption and implementation in Nigerian public sector. International Journal of Financial Research, 11(1), 434-446. https://doi.org/10.5430/ijfr.v11n1p434

Boriçi, A., \& Kruja, A. (2016). Determinants of firm's cash holding: Evidence from Shkodra region, Albania. International Journal of Economics, Commerce and Management, 4(4), 41-52.

Carrascal, M. (2010). Cash holdings, firm size and access to external finance: Evidence for the euro area. BANCO DE ESPAÑA Documentos De Trabajo.

Chukwu, N., Asaolu, T. O., Uwuigbe, O, R., Uwuigbe, U., Umukoro, E. O., Nassar, L., \& Alabi, O. (2019). The impact of basic forensic accounting skills on financial reporting credibility among listed firms in Nigeria. International Conference on Energy and Sustainable Environment, 331(1), 012041.

Dang, Ch. Y., Li, Zh. Ch., \& Yang, C. (2018). Measuring firm size in empirical corporate finance. Journal of Banking \& Finance, 86(C), 159-176. 
Eluyela, D. F., Adetula, D. T., Obasaju, O. B., Ozordi, E., Akintimehin, O., \& Popoola, O. (2019a). Foreign directors, indigenous directors and dividend payout structure in Nigerian deposit money banks. Banks and Bank System, 14(2), 1-14. https://doi.org/10.21511/bbs.14(2).2019.16

Eluyela, D. F., Akintimehin, O. O., Okere, W., Ozordi, E., Osuma, G. O., Ilogho, S. O., ... Oladipo, O. A. (2018a). Datasets for board meeting frequency and financial performance of Nigerian deposit money banks. Data in Brief. https://doi.org/10.1016/j.dib.2018.06.044

Eluyela, D. F., Akintimehin, O. O., Ozordi, E., Oladipo, O. A., Ilogho, S. O., \& Okere, W. (2018b). Board meeting frequency and firm performance: examining the nexus in Nigerian deposit money banks. Heliyon, 4, 850. https://doi.org/10.1016/j.heliyon.2018

Eluyela, D. F., Olajide, D., Tolase, O. A., Okere, W., Ogabi, M., \& Kafidipe, A. (2019b). Impact of Gender dichotomy on dividend payout policy in listed Nigerian financial services firm. Cogent Business and Management, 6, 1-10. https://doi.org/10.1080/23311975.2019.1687270

Ezeagba, C. E. (2014). The role of forensic accounting and quality assurance in financial reporting in selected commercial banks in Nigeria. International Journal of Economic Development Research and Investment, 5(2), 32-38.

Hilgen, K. E. (2015). The determinants of cash holdings: Evidence from German listed firms. University of Twente, School of Management and Governance.

Ijeoma, N. B. (2014). The effect of creative accounting on the Nigerian banking industry. International Journal of Managerial Studies and Research, 2(10), 13-21.

Jafari, S., Gord, A., \& Beerhouse, M. (2014). The effect of debt, firm size and liquidity on investment cash flow sensitivity of listed companies in Tehran stock exchange. Arabian Journal of Business and Management Review (Nigerian Chapter), 2(10), 94-102.

Mulyono, M., \& Khairurizka, R. (2009). The effect of financial ratios, firm size, and cash flow from operating activities in the interim report to the stock return. Chinese Business Review, 8(6), 44-55.

Nwanji, T. I., Howell, K. E., Faye, S., Otekunrin, A. O., Eluyela, D. F., Lawal, A. I., .. Eze, S. C. (2020). Impact of foreign direct investment on the financial performance of listed deposit banks in Nigeria. International Journal of Financial Research, 11(2), 323-347. https://doi.org/10.5430/ijfr.v11n2p323

Ojeka, S., Adegboye, A., Adegboye, K., Umukoro, O., Dahunsi, O., \& Ozordi, E. (2019). Corruption perception, institutional quality and performance of listed companies in Nigeria. Heliyon, 5(10). https://doi.org/10.1016/j.heliyon.2019.e02569

Okere, W., Eluyela, D. F., Lawal, A. I., Ibidunni, O., Eseyin, O., Popoola, O., \& Awe, T. (2019). Foreign expatriates on board and financial performance: a study of listed deposit money banks in Nigeria. The Journal of Social Science Research, 5(2), 418-423. https://doi.org/10.32861/jssr.52.418.423

Oladipo, O. A., Iyoha, O. F., Fakile, A. S., Asaleye, A. J., \& Eluyela, D. F. (2019a). Do government taxes have implications on manufacturing sector output? Evidence from Nigeria. Journal of Management Information and Decision Sciences, 22(3), 181-190.

Oladipo, O. A., Iyoha, O. F., Fakile, A. S., Asaleye, A. J., \& Eluyela, D. F. (2019b). Tax revenue and agricultural performance: evidence from Nigeria. Problems and Perspectives in Management, 17(3), 342-349. https://doi.org/10.21511/ppm.17(3).2019.27

Otekunrin, A. O., Nwanji, T. I., Agba, D. Z., Olowookere, J. K., Fakile, S. A., Ajayi, S. A., ... Oladiran, T. (2018). Outsourcing of accounting services and strategic cost management method: (A case study of Dangote flour PLC and Doyin Investment Nig. LTD). Proceedings of the 32nd International Business Information Management Association Conference, IBIMA 2018, 8452-8465.

Ozordi, E., Adetula, D. T., Eluyela, D. F., Aina, A., \& Ogabi, M. (2019). Corporate dynamism and cash holding decision in listed manufacturing firms in Nigeria. Problems and Perspectives in Management, 17(4), 1-12. https://doi.org/10.21511/ppm.17(4).2019.01

Ozordi, E., Eluyela, D. F., Uwuigbe, U., Uwuigbe, O. R., \& Nwaze, C. E. (2020). Gender diversity and sustainability responsiveness: evidence from Nigerian fixed money deposit banks. Problems and Perspectives in Management, 18(1), 119-129. https://doi.org/10.21511/ppm.18(1).2020.11 
Soumaya, H. (2012). The effect of debt, firm size and liquidity on investment-cash flow sensitivity. Macrothink Institute. International Journal of Accounting and Financial Reporting, 2(2).

Taani, K., \& Banykhaled, H. (2011). The effect of financial ratios, firm size and cash flows from operating activities on earnings per share: an applied study: on Jordanian industrial sector. International Journal of Social Sciences and Humanity Studies, 3(1), 98-116.

Tayem, G. (2017). The determinants of corporate cash holdings: The case of a small emerging market. International Journal of Financial Research, 8(1), 22-27. https://doi.org/10.5430/ijfr.v8n1p143

Tutor. (2018, October). How to read a cash flow statement. Retrieved from http://www.graduatetutor.com/accounting-tutors/how-to-read-a-cash-flow-statement/

Umukoro, E. O., Uwuigbe, O. R., Obigbemi, I., \& Uwuigbe, U. (2020). Social media cost and the levels of cash flow among listed banks in emerging economies in Africa. International Journal of Financial Research, 11(4), 370-383.

Umukoro, E. O., Uwuigbe, O. R., Uwuigbe, U., Adegboye, A., Ajetunmobi, O., \& Nwaze, C. (2019). Board expertise and sustainability reporting in listed banks in Nigeria. International Conference on Energy and Sustainable Environment, 331(1), 012048.

Umukoro, O. E., Eluyela, D. F., Ozordi, E., Inua, O. I., \& Balogun, S. B. (2020). Nollywood Accounting and Financial Performance: evidence from Nigerian Cinemas. International Journal of Financial Research, 11(2), 271-280. https://doi.org/10.5430/ijfr.v11n2p271

\section{Copyrights}

Copyright for this article is retained by the author(s), with first publication rights granted to the journal.

This is an open-access article distributed under the terms and conditions of the Creative Commons Attribution license (http://creativecommons.org/licenses/by/4.0/). 